\title{
Annual Report of the Korean Association of External Quality Assessment Service on Transfusion Medicine (2018)
}

Young Ae $\operatorname{Lim}^{1}$ and Hyun Soo Cho ${ }^{2}$

${ }^{1}$ Department of Laboratory Medicine, Ajou University School of Medicine;

${ }^{2}$ Department of Laboratory Medicine, Ajou University Hospital, Suwon, Korea

Corresponding author: Young Ae Lim Department of Laboratory Medicine, Ajou University School of Medicine, 164 World cup-ro, Yeongtong-gu, Suwon 16499, Korea

Tel: +82-31-219-5786

Fax: +82-31-219-5778

E-mail: limyoung@ajou.ac.kr

pISSN: $2384-2458$

eISSN: 2288-7261

\begin{abstract}
Herein, we report the results of the 2018 survey on the external quality assessment (EQA) scheme for the Transfusion Medicine Program (TMP) in Korea. The proficiency testing specimens were prepared at Ajou University Hospital and were sent to the participants biannually. The average accuracy rates for ten different test items on the regular survey were as follows: $\mathrm{ABO}$ typing, $99.5 \%-99.8 \%(\mathrm{~N}=841)$; $\mathrm{RhD}$ typing, $99.8 \%-100.0 \%(\mathrm{~N}=827)$; crossmatching, $89.4 \%-99.6 \%(\mathrm{~N}=708)$; ABO subtyping, $94.2 \%$ and $94.4 \%(\mathrm{~N}=53)$; $\mathrm{Rh}$ CcEe antigen testing, all $100.0 \%(\mathrm{~N}=51)$; weak D test, $80.9 \%(\mathrm{~N}=207)$ for the first trial and not graded for the second trial; antibody screening, 99.7\%-100.0\% ( $\mathrm{N}=304)$; direct antiglobulin test (DAT) using a polyspecific reagent, $98.9 \%-100.0 \%(\mathrm{~N}=264)$; DAT using an immunoglobulin-G monospecific reagent, all $100.0 \%(\mathrm{~N}=66)$; DAT using a C3d monospecific reagent, $97.0 \%-100.0 \%(\mathrm{~N}=67)$; antibody identification, $98.4 \%-100.0 \%$ $(\mathrm{N}=127)$; and $\mathrm{ABO}$ antibody titration, $84.6 \%-100.0 \%(\mathrm{~N}=73)$. There were approximately $10.5 \%$ more participants in the 2018 EQA scheme than that in 2017. Excellent survey results were obtained in the 2018 EQA scheme compared with those in 2017, except for the weak D test. The 2018 EQA scheme for the TMP should be helpful for improving the quality of the participating laboratories.
\end{abstract}

(J Lab Med Qual Assur 2019;41:65-74)

Key Words: Transfusion medicine, Quality improvement, Laboratory proficiency testing

\section{서론}

수혈 전 검사의 정확성은 환자의 생명과도 관련이 있으므로 정확성이 보증되어야 한다. 대부분 혈액은행에서 실시하고 있 는 검사의 원리는 적혈구와 혈장 혹은 혈청을 이용한 면역혈구 응집법 검사이다. 비록 일부 의료기관에 면역혈구응집법 검사 에 대한 자동화 장비가 도입되었기는 하나 아직도 수기법으로 시행하고 있는 의료기관이나 검사종목들이 존재한다. 이러한 수기법은 자동화에 비하여 검사결과의 편차가 클 수 있으며 사 무적인 오류 발생가능성도 크다고 볼 수 있다. 이러한 이유로 혈액은행검사의 외부정도관리 참여는 검사의 신뢰도를 평가 할 수 있는 매우 중요한 과정이라고 할 수 있다.

대한임상검사정도관리협회에서 2016년부터 시행한 차세대 신빙도조사사업의 수혈의학 관련 검사들은 다음과 같이 4 개의 프로그램으로 나뉘어 10 가지의 항목으로 시행하고 있다[1].
(1) 일반수혈검사: $\mathrm{ABO}$ typing (ABO 혈액형), RhD typing (RhD 혈액형), crossmatching(교차시험); (2) 수혈항원검 사, 특수: $\mathrm{ABO}$ subtyping ( $\mathrm{ABO}$ 아형 혈액형), $\mathrm{Rh} \mathrm{CcEe}$ antigen testing (Rh $\mathrm{CcEe}$ 항원검사), weak D test(약 D검 사); (3) 수혈항체검사, 일반: antibody screening(비예기항체 선별검사), direct antiglobulin test(직접항글로불린검사); (4) 수혈항체검사, 특수: antibody identification(비예기항체 동정 검사), $\mathrm{ABO}$ antibody titration ( $\mathrm{ABO}$ 항체 역가검사). 이 4 개의 수혈의학프로그램은 2016년부터 동일한 수혈의학프로그 램 관리자에 의하여 관리되고 있다.

이에 저자들은 2018년에 4개의 수혈의학프로그램에서 실시 한 10 가지의 검사항목에 대하여 2차에 걸쳐 신빙도조사를 실 시하였고, 기관별 검사방법에 대한 결과와 실시하였던 사업내 용을 보고하고자 한다. 


\section{Journal of LABORATORY MEDICINE and QUALITY ASSURANCE}

\section{Young Ae Lim et al • Annual Report (2018) for Transfusion Medicine EQA}

\section{재료 및 방법}

\section{1. 조사항목}

조사항목은 서론에서 언급한 바와 마찬가지로 $\mathrm{ABO}$ 혈액형, $\mathrm{RhD}$ 혈액형, 교차시험, $\mathrm{ABO}$ 아형 혈액형, $\mathrm{Rh} \mathrm{CcEe}$ 항원검 사, 약 $\mathrm{D}$ 검사, 비예기항체 선별검사, 직접항글로불린검사, 비 예기항체 동정검사, $\mathrm{ABO}$ 항체 역가검사의 10 가지 항목에 대 한 신빙도조사를 실시하였다.

\section{2. 외부신빙도조사 물질용 제조}

검체 제조는 2016년도부터 차세대 신빙도조사사업을 위한 자가제조물질 개발의 용역연구를 맡은 아주대학교병원에서 다 음과 같이 제조하였다[2]. 검체 제조에 사용된 혈액제제들은 대한적십자사와 한마음혈액원으로부터 생명윤리심의를 득한 후에 사용하였다. 자가제조된 모든 검체는 객관적 판독을 위 하여 검사자 2 인이 각각 시험관법과 겔카드법으로(Bio-Rad Laboratories, DiaMed GmbH, Cressier, Switzerland) 검사 하여 결과 및 혈구 응집 정도를 확인하였다. 아주대학교병원에 서 제조되고 분주 후 표식이 붙여진 외부신빙도조사 물질들은 대한임상검사정도관리협회로 운반되어 포장된 후 각 참여기관 으로 발송되었다. 외부신빙도조사 검체는 1차 4월 17일, 2 차는 9월 18일에 계약 택배를 이용하여 각각 발송하였다. 검사결과 는 차세대 신빙도조사사업 홈페이지에 입력하도록 하였다.

\section{1) 혈구부유액 제조}

신빙도조사 검사항목(각 회차당 검체 수)인 $\mathrm{ABO}$ 혈액형 의 혈구형 검사(3개), $\mathrm{RhD}$ 혈액형(3개), $\mathrm{ABO}$ 아형 혈액형 (1개), $\mathrm{Rh} \mathrm{CcEe}$ 항원검사(1개), 그리고 약 $\mathrm{D}$ 검사(1개)를 위 한 적혈구 부유액은 목적하고자 하는 혈액형을 가진 혈액을 혈구보존액인 Alsever's solution (Hemo Bioscience Inc., Morrisville, NC, USA)을 사용하여 희석하였다. ABO 혈액 형의 혈구형 검사와 $\mathrm{RhD}$ 혈액형 검사용 혈구부유액은 자동 화 장비에도 사용이 가능하도록 하였다. 이를 위하여 $20 \%$ 의 재조합 전혈이 되도록 동형의 신선동결혈장과 Alsever's solution (Hemo Bioscience Inc.)으로 희석하였고, ABO 아 형 혈액형, $\mathrm{Rh} \mathrm{CcEe}$ 항원검사 그리고 약 $\mathrm{D}$ 검사용 적혈구 부유 액은 Alsever's solution (Hemo Bioscience Inc.)으로 5\%가 되 도록 하였다. 교차시험용 적혈구 부유액은 3 개의 $\mathrm{ABO}$ 혈액 형의 혈구형 검사용 검체 중 하나를 사용하도록 하였다. $\mathrm{ABO}$ 아형 혈액형과 약 D검사 검체는 $\mathrm{CPDA}$ (citrate phosphate dextrose adenine) -1 혈액 백에서 분리된 농축적혈구를 사용 하였다 1,2$]$. 동일한 $\mathrm{ABO}$ 혈액형의 혈액백의 혼주 시는 무균 봉합기로 연결하여 혼합한 다음 분주하였다.

\section{2) 혈장용 검체 제조}

$\mathrm{ABO}$ 혈청 검사용은 혈구형과 동일한 $\mathrm{ABO}$ 혈액형, $\mathrm{ABO}$ 항체 역가검사용은 $\mathrm{O}$ 형의 성분채혈혈장을 사용하였다. 혈액 백의 혼주 시는 무균봉합기로 연결하여 혼합한 다음 분주하였 다. $\mathrm{ABO}$ 혈액형의 혈청용 검체가 혈구형에 비하여 혈구응집 이 약하여 불일치를 보일 경우 단클론 항체 immunoglobulin $\mathrm{M}$ 시약인 항-A와 항- $\mathrm{B}$ 를 주사기에 담아 코플러를 소독한 후 주사기를 꽂아 항혈청을 주입하여 강도를 높였다.

\section{3) 재조합 혈장 검체 제조}

신빙도조사 검사항목(각 회차당 검체 수)인 교차시험(3개), 비예기항체 선별검사(3개)는 비예기항체 동정검사(2개)는 항 혈청에 성분채혈혈장으로 희석하여 재조합하였다. 교차시험 양성 검체는 항글로불린 단계에서만 검출되고 그 외의 단계에 서는 검출되지 않거나 약하게 검출될 정도의 항혈청의 항체 역 가를 희석하여 검체를 제조하였는데, 상품화된 인간유래 다클 론성 anti-D (DiaMed $\mathrm{GmbH}$ )를 $\mathrm{AB}$ 형 성분채혈혈장에 희석 하여 사용하였다[1,2].

비예기항체 선별검사용 양성 검체로는 1 회차, 2 회차 항- $\mathrm{D}$ 항체를 발송하였고, 동정용 양성 검체로는 1 회차 항- $\mathrm{E}$ 항체, 항- $\mathrm{Fy}^{\mathrm{b}}$ 항체를, 2 회차 항-C와 항-D 항체, 항-K 항체를 발송하 였다. 검체는 상품화된 항혈청 시약을 각각 희석하여 사용하였 는데, 사용된 항혈청 시약의 종류는 각각 다클론성 항-D 항체 (DiaMed $\mathrm{GmbH}$ ), 단클론성 항-E, 항-C, 항-K 항체(Diagast, Parc Eurasanté, France), 다클론성 항-Fy 항체(Diagast)였 다. 희석 시는 $\mathrm{AB}$ 혈액형의 성분채혈혈장에 희석하였다 $[1,2]$.

\section{4) 직접항글로불린검사용 혈구 제조}

양성 직접항글로불린검사용 검체는 인간유래 다클론성 항-D 항체 (DiaMed $\mathrm{GmbH}$ )를 사용하여 인위적으로 감작시 킨 혈구를 사용하였다. 음성 직접항글로불린검사용 혈구는 직 접항글로불린검사 결과 음성인 적혈구를 사용하였다. 양성 및 음성 혈구들은 혈구보존액인 Alsever's solution (Hemo Bioscience Inc.)에 10\%로 희석하여 이용하였다.

\section{3. 결과 판정 및 분석 검체}

해당 검사를 시행하기에 적절하지 않은 slide법은 분석에서 제외하였다. 교차시험의 경우 음성으로 적합 판정을 한 검체에 대해서는 응집이 없다고 보고한 경우만 정답으로 간주하였다. $\mathrm{Rh} \mathrm{CcEe}$ 항원검사와 직접항글로불린검사의 경우 $1+$ 이상을 양성으로 간주하여 양성 검체의 정답률을 산정하였다. $\mathrm{ABO}$ 항체 역가검사의 허용범위는 참여기관이 10 기관 이상인 검사 


\section{Journal of LABORATORY MEDICINE and QUALITY ASSURANCE}

\section{Young Ae Lim et al • Annual Report (2018) for Transfusion Medicine EQA}

법에 대하여 최빈도와 상하 단계씩 추가하였고, 이 범위에 속 하는 참여기관이 $80 \%$ 를 넘지 않을 경우에는 최빈도와 상하 단계 근처의 빈도수가 많은 단계를 더 추가하여 결정하였다. 참여기관이 10 기관 미만인 경우에는 code 501 을 사용하여 평 가하지 않았다. 교차시험의 방법별 혈구응집 정도와 직접항글 로불린검사의 혈구응집 정도는 안내문에 공지한 대로 해당 검 체에 대해 합의된 결론을 도출하고 평가하였으나, 검사항목이 교육목적이라 인증평가에는 불포함하는 code 520 을 사용하였 다. 또한 해당 검체에 대해 합의된 결론을 도출할 수 없을 경우 에는 code 505 를 사용하였고, 해당 기관이 사용하는 기기 및 시약에서는 합의된 결론이 도출되었으나 의도된 결과 또는 연 관된 검사종목의 결과와 상이하여 평가를 할 수 없는 경우에는 code 506을 사용하여 모두 평가에서 제외하였다.

\section{결과}

\section{1. 일반수혈검사}

\section{1) $A B O$ 와 $R h D$ 혈액형}

$\mathrm{ABO}$ 혈액형검사는 2 차에 걸쳐 총 6 개의 검체로 실시하였
고 평균 참여기관 수는 841 개 기관으로 전년도 대비 $17.7 \%$ 가 증가하였고, 정답률은 99.5\%-99.8\%를 나타냈다(Table 1). 1 차(2차)의 혈구형 검사법은 슬라이드법 $54.2 \%$ (54.3\%), 시험 관법 $37.3 \%$ (36.7\%) 순이었으며, 1차(2차)의 혈청형 검사법 은 시험관법이 $81.3 \%$ (81.7\%), 슬라이드법 $11.1 \%$ (10.1\%) 순으로 나타났다.

$\mathrm{RhD}$ 혈액형검사도 2 차에 걸쳐 총 6 개의 검체로 실시하였 고, 평균 참여기관 수는 827 개 기관으로 전년도 대비 $19.0 \%$ 가 증가하였고, 정답률은 99.5\%-100.0\%를 나타내어 작년도 에 비하여 정답률이 소폭 증가하였다(Table 2). 1차(2차)의 검 사법은 1 차에서는 시험관법이 $44.2 \%$ (42.8\%), 슬라이드법 $47.3 \%(48.1 \%)$ 순이었다.

\section{2) 교차시험}

교차시험검사는 2 차에 걸쳐 총 6 개의 검체가 사용되었으며, 평균 참여기관 수는 708 개 기관으로 전년도 대비 $14.6 \%$ 가 증 가하였다. 적합 검체는 $99.2 \%-99.6 \%$, 부적합 검체는 $89.4 \%$ 와 $92.1 \%$ 의 교차시험 판정 정답률을 보여 $96.5 \%$ 의 평균 정답 률을 보였다(Table 3). 부적합 검체의 경우 각 방법별로 분석 한 결과, 시험관법의 식염수단계와 $37^{\circ} \mathrm{C}$ 알부민단계에서는 대

Table 1. Number (\%) of participants in the proficiency testing for ABO blood grouping in 2018

\begin{tabular}{|c|c|c|c|c|c|c|c|c|}
\hline Trial & Specimen & Total & A & B & $\mathrm{O}$ & $\mathrm{AB}$ & Dis & $\begin{array}{l}\text { Intended } \\
\text { response }\end{array}$ \\
\hline \multirow[t]{2}{*}{1} & BB-18-01 & 839 (100.0) & $2(0.2)$ & $836(99.7)$ & - & - & $1(0.1)$ & B \\
\hline & BB-18-03 & $839(100.0)$ & 837 (99.8) & - & $1(0.1)$ & - & $1(0.1)$ & $\mathrm{A}$ \\
\hline 2 & BB-18-07 & $842(100.0)$ & $1(0.1)$ & $838(99.5)$ & & - & $3(0.4)$ & B \\
\hline
\end{tabular}

Values are presented as number (\%), unless otherwise stated.

Abbreviation: Dis, discrepancy between cell typing and serum typing.

Table 2. Number (\%) of participants in the proficiency testing for RhD typing in 2018

\begin{tabular}{|c|c|c|c|c|c|c|c|}
\hline Trial & Specimen & Total & Positive & Variant & Negative & NA & $\begin{array}{l}\text { Intended } \\
\text { response }\end{array}$ \\
\hline \multirow[t]{2}{*}{1 st } & BB-18-01 & $823(100.0)$ & $823(100.0)$ & - & - & - & Positive \\
\hline & BB-18-03 & $823(100.0)$ & $3(0.4)$ & $1(0.1)$ & 819 (99.5) & - & Negative \\
\hline \multirow[t]{2}{*}{ 2nd } & BB-18-07 & $831(100.0)$ & $1(0.1)$ & $1(0.1)$ & $829(99.8)$ & - & Negative \\
\hline & BB-18-09 & $831(100.0)$ & $831(100.0)$ & - & - & - & Positive \\
\hline
\end{tabular}

Abbreviation: NA, not available. 


\section{Journal of LABORATORY MEDICINE and QUALITY ASSURANCE}

Young Ae Lim et al • Annual Report (2018) for Transfusion Medicine EQA

부분의 기관에서 음성으로 보고한 반면, 대부분의 시험관법 항 글로불린단계와 원주응집법은 $1+$ 이상의 응집을 나타내었다

(Fig. 1).

\section{2. 특수 수혈항원검사}

\section{1) $\mathrm{ABO}$ 아형 혈액형}

평균 참여기관 수는 53 개 기관으로 전년도 대비 $3.9 \%$ 가 증
가하였다. 1 차 검체는 $\mathrm{A}_{2} \mathrm{Bw}$ 형으로 $94.2 \%$ (49/51)의 정답률 을 보였는데 항-B 시약과의 반응에서 $100.0 \%$ 기관에서 혼합 시야를 포함하여 trace부터 $3+$ 까지의 응집을 보고하였으며, 2 개 기관을 제외한 $96.2 \%$ 에서 B 아형을 검출하였다. 항- $\mathrm{H}$ 시 약과의 반응에서 $1+$ 이상을 보고한 기관은 $98.0 \%$ 였다. 2 차

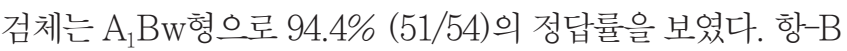
시약과의 반응에서 혼합시야를 포함하여 trace부터 $3+$ 까지의 응집을 보고한 기관은 $96.3 \%$ 였으며 2기관을 제외한 $96.3 \%$ 에

Table 3. Number and percentage of participants in the proficiency testing for blood crossmatching in 2018

\begin{tabular}{|c|c|c|c|c|}
\hline Trial (RBC) & Specimen & Intended response & Results & Number (\%) \\
\hline \multirow[t]{4}{*}{ 1st (BB-18-02) } & BB-18-04 & Compatible & Acceptable & $706(99.6)$ \\
\hline & & & Unacceptable & $3(0.4)$ \\
\hline & & & Unacceptable & $75(10.6)$ \\
\hline & BB-18-06 & Compatible & Acceptable & 703 (99.2) \\
\hline \multirow[t]{4}{*}{ 2nd (BB-18-08) } & BB-18-10 & Compatible & Acceptable & 703 (99.4) \\
\hline & & & Unacceptable & $4(0.6)$ \\
\hline & BB-18-11 & Incompatible & Acceptable & $651(92.1)$ \\
\hline & & & Unacceptable & $56(7.9)$ \\
\hline
\end{tabular}

Abbreviation: RBC, red blood cell.

A
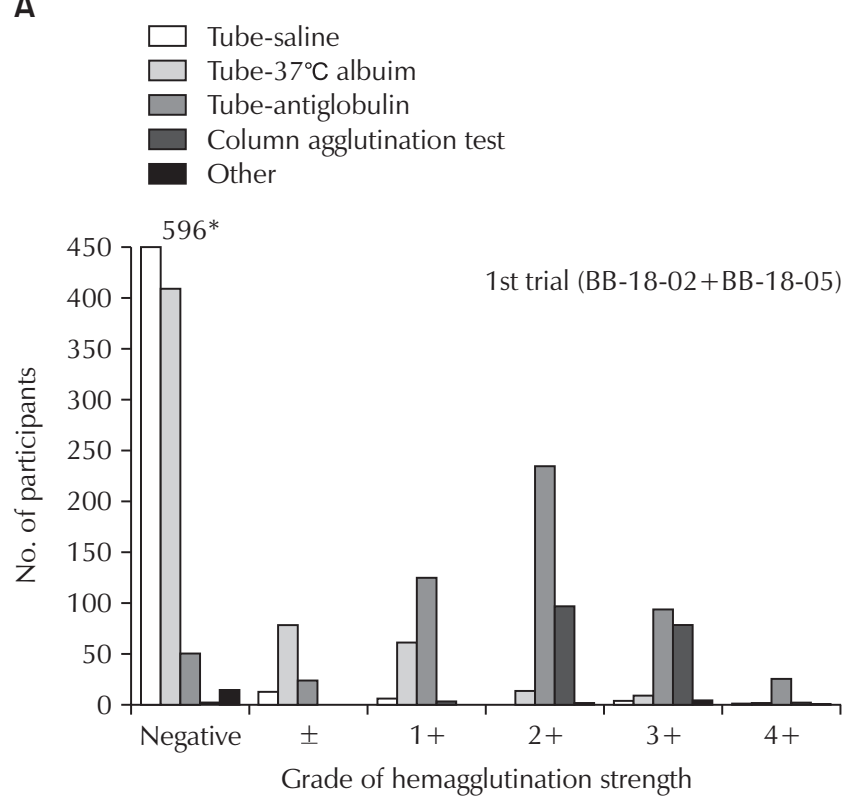

B
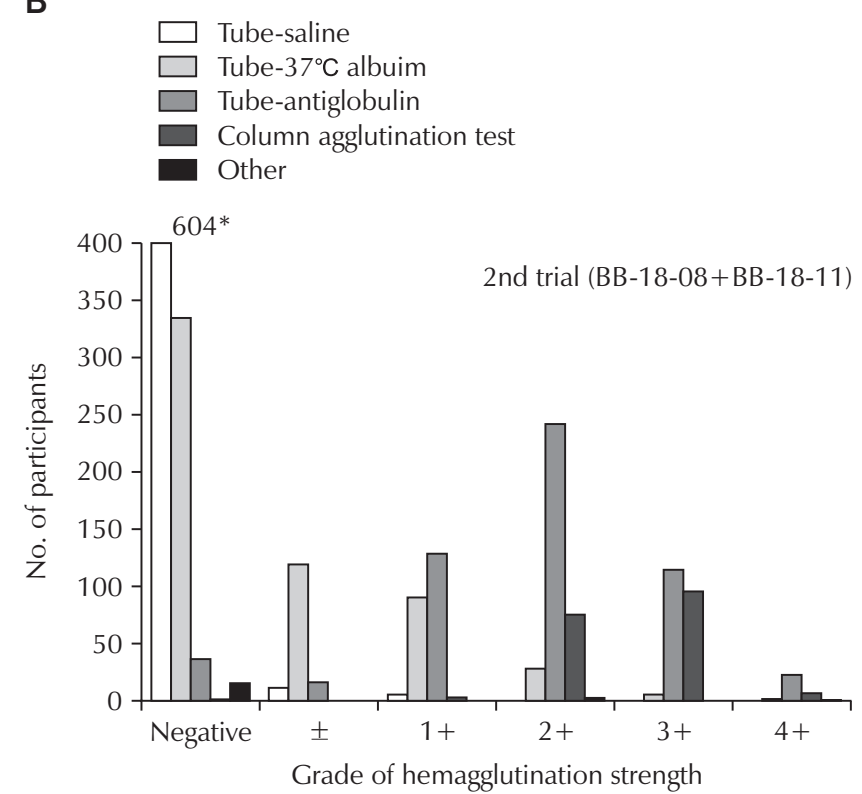

Fig. 1. (A, B) Number of participants (Y axis) according to the grade of hemagglutination strength (X axis) of incompatible samples for blood crossmatching in 2018. ${ }^{*}$ The number of participants using tube-saline. 


\section{Journal of LABORATORY MEDICINE and QUALITY ASSURANCE}

\section{Young Ae Lim et al • Annual Report (2018) for Transfusion Medicine EQA}

서 $\mathrm{B}$ 아형을 검출하였다. 항- $\mathrm{H}$ 시약과의 반응에서 2 개 기관을 제외하고는 모든 기관에서 $1+$ 이상을 보고하여 $96.2 \%$ 였다 (Table 4).

\section{2) Rh CcEe 항원검사}

$\mathrm{Rh} \mathrm{CcEe}$ 항원검사는 1 차와 2 차 모두 51 개 기관에서 참여하 였으며, 1 차와 2차 검체 모두 $\mathrm{CcEe}$ 검체를 발송하였는데, 혈 액형 판정을 실시한 기관은 1 차 47 개 기관 그리고 2 차 46 개 기 관의 검체에서만 보고하였으며, $2+$ 를 보고한 일부 기관을 제 외하고는 모두 $3+$ 이상의 혈구응집을 보고하여 2차 검체의 C 항원을 제외한 나머지 항원은 $3+$ 이상을 정답으로 간주하였 다(Table 5).

\section{3) 약 $D$ 검사}

평균 참여기관 수는 207 개 기관으로 전년도 대비 $37.5 \%$ 가 증가하여 수혈의학프로그램 종목 중 가장 많이 증가하였다. 1 차에 발송된 검체는 $72.5 \%$ 기관에서 $\mathrm{RhD}$ 혈액형검사에서는 음성을 보였으나 $80.9 \%$ 에서 D 변이형으로 보고하였다. 반면 2 차에 발송된 검체는 $99.0 \%$ 기관에서 $\mathrm{RhD}$ 혈액형검사에서 음성을 보였으며 $34.8 \%$ 만이 의도하였던 D 변이형으로 보고
하였고, D 음성으로 보고한 기관도 $63.8 \%$ 나 되어 의도한 답 변과 상당수의 기관들이 보고한 답변들 간의 상이한 차이를 보 여 code 506으로 처리하고 평가에서 제외하였다(Table 6).

\section{3. 일반 수혈항체검사}

\section{1) 비예기항체 선별검사}

평균 참여기관 수는 304 기관으로 전년도 대비 $4.3 \%$ 가 증 가하였고, 비예기항체 선별검사는 1 차와 2 차의 경우 모두 2 개의 양성 검체와 1 개의 음성 검체를 발송하였다. 1 차 검체는 993\%-100.0\%, 그리고 2차 검체에서는 99.7\%-100.0\%의 정 답률을 보였다(Table 7). 1차(2차) 검사법의 비율은 원주응집 법 94.4\% (94.0\%), 시험관법 3.6\% (2.0\%), 그리고 나머지 검사법이 $3.6 \%(4 \%)$ 를 차지하였다.

2) 직접항글로불린검사

직접항글로불린검사는 2 차에 걸쳐 총 6 개의 검체가 사용되 었다. 다특이성 항글로불린검사는 4 개의 음성 검체에 대하여 99.2\%-100.0\%와 2개의 양성 검체에 대하여 98.9\%-100.0\% 의 정답률을 보였으며, 평균 참여기관 수는 264 개 기관으로 전

Table 4. Number (\%) of participants in the proficiency testing for ABO subtyping in 2018

\begin{tabular}{|c|c|c|c|c|c|c|c|}
\hline \multirow{3}{*}{$\begin{array}{l}\text { Trial (specimen) } \\
\text { 1st (BGS-18-01) }\end{array}$} & \multirow{3}{*}{$\begin{array}{l}\text { Category } \\
\text { Number }\end{array}$} & \multicolumn{4}{|c|}{ Anti-sera } & \multirow{2}{*}{\multicolumn{2}{|c|}{ ABO subgroup }} \\
\hline & & \multirow{2}{*}{$\frac{\text { Anti-A }}{52}$} & \multirow{2}{*}{$\frac{\text { Anti-B }}{52}$} & \multirow{2}{*}{$\begin{array}{c}\text { Anti-A1 } \\
52\end{array}$} & \multirow{2}{*}{$\begin{array}{c}\text { Anti-H } \\
49\end{array}$} & & \\
\hline & & & & & & $\mathrm{A}_{2} \mathrm{~B}$ & $2(3.8)^{\star}$ \\
\hline & Negative & - & - & $52(100.0)$ & $1(2.0)$ & $\mathrm{A}_{2} \mathrm{Bw}$ & $49(94.2)$ \\
\hline & \pm & - & $1(1.9)^{*}$ & - & - & $\mathrm{AwBw}$ & $1(1.9)^{*}$ \\
\hline & $1+$ & - & $5(9.6)$ & - & $2(4.1)$ & - & - \\
\hline & $3+$ & $3(5.8)$ & $10(19.2)$ & - & $21(42.9)$ & - & - \\
\hline & $4+$ & $49(94.2)$ & - & - & $21(42.9)$ & - & - \\
\hline & $\mathrm{MF}$ & - & $14(26.9)$ & - & - & - & - \\
\hline \multirow[t]{5}{*}{ 2nd (BGS-18-04) } & Number & 54 & 54 & 54 & 52 & $\mathrm{~A}_{1}$ & $2(3.7)^{*}$ \\
\hline & $2+$ & - & $5(9.3)$ & $2(3.7)$ & $24(46.2)$ & - & - \\
\hline & $3+$ & - & - & $3(5.7)$ & $2(3.8)$ & - & - \\
\hline & $4+$ & $54(100.0)$ & - & $47(88.7)$ & - & - & - \\
\hline & MF & - & $18(33.3)$ & - & - & - & - \\
\hline
\end{tabular}

Values are presented as number (\%), unless otherwise stated.

Abbreviation: MF, mixed field agglutination.

*Unacceptable responses for ABO subgrouping. 
Journal of LABORATORY MEDICINE and QUALITY ASSURANCE

Young Ae Lim et al • Annual Report (2018) for Transfusion Medicine EQA

Table 5. Number (\%) of participants in the proficiency testing for Rh CcEe antigen typing in 2018

\begin{tabular}{|c|c|c|c|c|c|c|}
\hline \multirow{2}{*}{ Trial (specimen) } & \multirow{2}{*}{ Category } & \multicolumn{4}{|c|}{ Anti-sera } & \multirow{2}{*}{ Phenotype } \\
\hline & & $\mathrm{C}$ & $\mathrm{E}$ & c & $\mathrm{e}$ & \\
\hline \multirow[t]{3}{*}{ 1st (BGS-18-02) } & Number & 51 & 51 & 51 & 51 & CcEe 47 (100.0) \\
\hline & $2+$ & $1(2.0)$ & $1(2.0)$ & $2(3.9)$ & - & \\
\hline & $3+$ & $17(33.3)$ & $15(29.4)$ & $13(25.5)$ & $13(25.5)$ & \\
\hline \multirow[t]{4}{*}{ 2nd (BGS-18-05) } & Number & 51 & 51 & 51 & 51 & CcEe 46 (100.0) \\
\hline & Negative & - & - & - & - & \\
\hline & $1+$ & - & - & - & - & \\
\hline & $2+$ & $1(2.0)$ & $2(3.9)$ & $5(9.8)$ & $4(7.8)$ & \\
\hline
\end{tabular}

Values are presented as number (\%), unless otherwise stated.

Table 6. Number (\%) of participants in the proficiency testing for weak D test in 2018

\begin{tabular}{lccccc}
\hline \multirow{2}{*}{$\begin{array}{c}\text { Trial } \\
\text { (specimen })\end{array}$} & \multicolumn{2}{c}{ 1 (BGS-18-03) } & & \multicolumn{2}{c}{ 2 (BGS-18-06) } \\
\cline { 2 - 3 } \cline { 5 - 6 } Number & RhD & Weak D & & RhD & Weak D \\
\hline Negative & $150(72.5)^{*}$ & $3(1.4)$ & & $203(99.0)^{*}$ & $131(63.6)$ \\
\pm & $32(15.5)^{*}$ & - & & $1(0.5)^{*}$ & $23(11.2)$ \\
$1+$ & $18(8.7)^{*}$ & $19(9.1)$ & - & $39(18.9)$ \\
$2+$ & $7(3.4)^{*}$ & $54(26.0)$ & $1(0.5)^{*}$ & $11(5.3)$ \\
$3+$ & - & $76(63.5)$ & - & $2(1.0)$ \\
$4+$ & - & $52(25.0)$ & & - \\
Not done & - & $4(1.9)$ & & - \\
D positive & \multicolumn{2}{c}{$2(1.0)^{\dagger}$} & & \multicolumn{2}{c}{$3(1.4)^{*}$} \\
D variant & $169(80.9)$ & & $72(34.8)^{*}$ \\
D negative & \multicolumn{2}{c}{$38(18.2)^{\dagger}$} & & $132(63.8)^{*}$ \\
\hline
\end{tabular}

Values are presented as number (\%), unless otherwise stated. *Not graded due to lack of participants' consensus or participants' consensus different from the intention. ${ }^{\dagger}$ Unacceptable responses for weak $\mathrm{D}$ testing.

년도 대비 $3.3 \%$ 가 증가하였다. Immunoglobulin G 단특이성 항글로불린검사는 6 개의 모든 검체에서는 예년처럼 $100.0 \%$ 의 정답률을 보였다. 그러나 $\mathrm{C} 3 \mathrm{~d}$ 단특이성 항글로불린검사 의 경우, 6 개의 음성 검체에서 $97.0 \%-100.0 \%$ 의 정답률을 보 였다(Table 8). 참가기관들은 원주응집법과 시험관법을 사 용하고 있는데, 다특이성 항글로불린검사의 원주응집법과 시 험관법의 사용비율은 경우 1 차 $68.9 \%$ 와 $31.1 \%, 2$ 차의 경우
Table 7. Number (\%) of participants in the proficiency testing for antibody screening in 2018

\begin{tabular}{|c|c|c|c|c|c|}
\hline \multirow{2}{*}{ Trial } & \multirow{2}{*}{ Specimen } & \multirow{2}{*}{$\begin{array}{c}\text { Num- } \\
\text { ber }\end{array}$} & \multicolumn{2}{|c|}{ Result } & \multirow{2}{*}{ Intended } \\
\hline & & & Positive & Negative & \\
\hline \multirow[t]{3}{*}{$1 \mathrm{st}$} & BBG-18-01 & 305 & $305(100.0)$ & . & Positive \\
\hline & BBG-18-02 & 305 & $1(0.3)^{\star}$ & 304 (99.7) & Negative \\
\hline & BBG-18-03 & 305 & $303(99.3)$ & $2(0.7)^{*}$ & Positive \\
\hline \multirow[t]{3}{*}{2 nd } & BBG-18-07 & 300 & - & $300(100.0)$ & Negative \\
\hline & BBG-18-08 & 300 & 299 (99.7) & $1(0.3)^{*}$ & Positive \\
\hline & BBG-18-09 & 300 & $300(100.0)$ & - & Positive \\
\hline
\end{tabular}

Values are presented as number (\%), unless otherwise stated.

*Unacceptable responses for antibody screening.

$69.7 \%$ 와 $30.3 \%$ 였다.

\section{4. 특수 수혈항체검사}

\section{1) 비예기항체 동정검사}

평균 참여기관 수는 127 기관으로 전년도 대비 $3.4 \%$ 가 증가 하였고, 각 항체별 동정검사의 정답률은 항- $\mathrm{E}$ 항체와 항- $\mathrm{K}$ 항 체는 모두 $100.0 \%$, 항-Fy 항체는 $98.4 \%$ 의 우수한 정답률을 나타내었다. 항-C와 항-D 항체 조합인 경우 $97.6 \%$ 의 정답률 을 나타내었으나 항-D 항체만 검출한 기관이 2 개 기관 그리고 항체를 검출하지 못한 기관 1 개 기관으로 이들 3 개 기관의 결 과는 오답으로 처리하였다(Table 9). 
Journal of LABORATORY MEDICINE and QUALITY ASSURANCE

Young Ae Lim et al • Annual Report (2018) for Transfusion Medicine EQA

Table 8. Number (\%) of participants in the proficiency testing for direct antiglobulin test in 2018

\begin{tabular}{|c|c|c|c|c|c|c|}
\hline \multirow{2}{*}{ Trial } & \multirow{2}{*}{ Antiglobulin } & \multirow{2}{*}{ Specimen } & \multirow{2}{*}{ Number } & \multicolumn{2}{|c|}{ Result } & \multirow{2}{*}{ Intended response } \\
\hline & & & & Positive & Negative & \\
\hline \multirow[t]{7}{*}{1 st } & Polyspecific & BBG-18-04 & 264 & $261(98.9)$ & $3(1.1)$ & Positive \\
\hline & & BBG-18-06 & & $1(0.4)^{*}$ & $263(99.6)$ & Negative \\
\hline & Anti-IgG & BBG-18-04 & 66 & $66(100.0)$ & - & Positive \\
\hline & & BBG-18-06 & & - & $66(100.0)$ & Negative \\
\hline & Anti-C3d & BBG-18-04 & 67 & $2(3.0)^{*}$ & $65(97.0)$ & Negative \\
\hline & & BBG-18-05 & & - & $67(100.0)$ & Negative \\
\hline & & BBG-18-06 & & $1(1.5)^{\star}$ & $66(98.5)$ & Negative \\
\hline \multirow{6}{*}{ 2nd } & Anti-IgG & BBG-18-10 & 65 & - & $65(100.0)$ & Negative \\
\hline & & BBG-18-11 & & - & $65(100.0)$ & Negative \\
\hline & & BBG-18-12 & & $65(100.0)$ & - & Positive \\
\hline & Anti-C3d & BBG-18-10 & 66 & - & $66(100.0)$ & Negative \\
\hline & & BBG-18-11 & & - & $66(100.0)$ & Negative \\
\hline & & BBG-18-12 & & $2(3.0)^{*}$ & $64(97.0)$ & Negative \\
\hline
\end{tabular}

Values are presented as number (\%), unless otherwise stated.

Abbreviation: IgG, immunoglobulin G.

${ }^{\star}$ Unacceptable responses for direct antiglobulin test.

Table 9. Number (\%) of participants in the proficiency testing for antibody identification in 2018

\begin{tabular}{|c|c|c|c|c|c|}
\hline \multirow{2}{*}{ Trial } & \multirow{2}{*}{ Specimen } & \multirow{2}{*}{ Number } & \multicolumn{2}{|c|}{ Intended response } & \multirow{2}{*}{ Other responses (no. of participants) } \\
\hline & & & Antibody & Number (\%) & \\
\hline 1 & BBS-18-01 & 128 & Anti-E & $128(100.0)$ & \\
\hline \multirow[t]{2}{*}{2} & BBS-18-04 & 126 & Anti-C+anti-D & $123(97.6)$ & Anti-D (2), not detected (1) \\
\hline & BBS-18-05 & 126 & Anti-K & $126(100.0)$ & \\
\hline
\end{tabular}

\section{2) $\mathrm{ABO}$ 항체 역가검사}

평균 참여기관 수는 73 기관으로 전년도와 동일하였고, 각 방법별 $\mathrm{ABO}$ 항체 역가검사 결과는 Table 10 과 같으며 허용 범위는 굵은 글씨로 표시하였다. 항-A 항체의 경우 허용범위 에 드는 참여기관 비율은 1 차와 2 차는 각각 시험관 즉시원침 법은 모두 $97.6 \%$, 시험관 실온배양법과 시험관 항글로불린 법 모두 100.0.0\%, 원주응집 실온법 모두 $91.7 \%$, 원주응집 항글로불린법은 모두 $92.6 \%$ 와 $81.5 \%$ 였다. 항-B 항체의 경 우 허용범위에 드는 참여기관 비율은 1 차와 2 차는 각각 시험 관 즉시원침법은 모두 $94.6 \%$ 와 $97.3 \%$, 시험관 실온배양법은
$100.0 \%$ 와 $95 \%$, 시험관 항글로불린법 $88.2 \%$ 와 $100.0 \%$, 원 주응집 실온법 모두 $91.7 \%$, 원주응집 항글로불린법은 $96.4 \%$ 와 $100.0 \%$ 였다(Table 10). 검사법은 시험관 즉시원침법을 사 용하는 기관이 평균 39 개 기관으로 가장 많았으며, 원주응집 항글로불린법 28 개 기관, 시험관 실온배양법과 시험관 항글로 불린법이 각각 17 개 기관, 원주응집 실온법 12 개 기관 순으로 나타났다. 


\section{Journal of LABORATORY MEDICINE and QUALITY ASSURANCE}

Young Ae Lim et al • Annual Report (2018) for Transfusion Medicine EQA

Table 10. Number of participants according to the techniques for ABO antibody titration in 2018

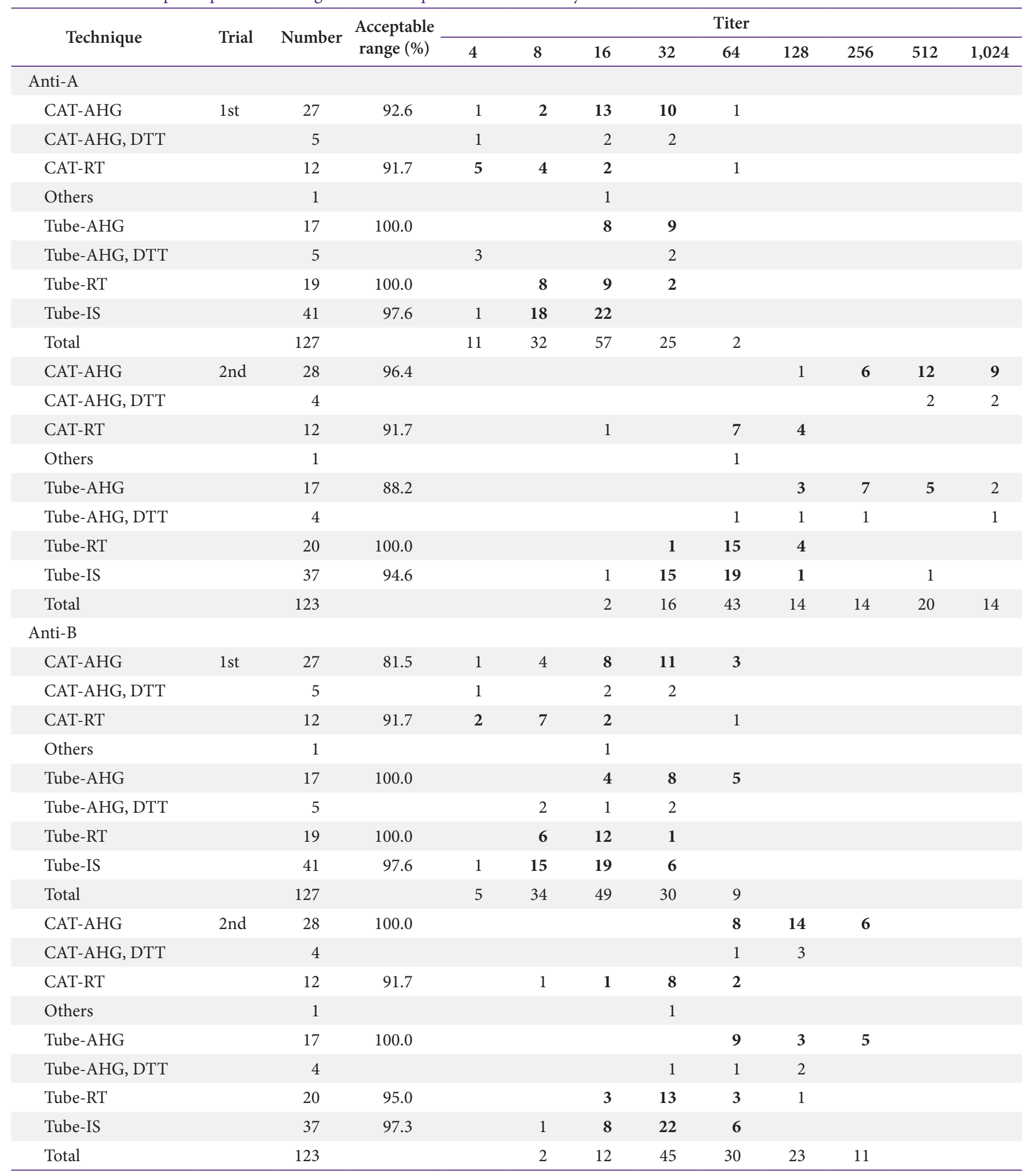

Bold type signifies acceptable range.

Abbreviations: CAT, column agglutination technology; AHG, indirect anti-human globulin test; DTT, dithiothreitol; RT, room temperature incubation; IS, immediate spin. 


\section{고찰}

검사에 참여한 기관 수는 2017년도에 비하여 2018년도에 평균 $10.5 \%$ 증가하였는데, 전년도에 비하여 가장 많이 증가 한 검사종목은 약 $\mathrm{D}$ 검사로 $37.5 \%$ 가 증가하였다. 이 외에도 $\mathrm{ABO}$ 혈액형검사 $17.7 \%, \mathrm{RhD}$ 혈액형검사 $19 \%$, 그리고 교차 시험의 경우 $14.6 \%$ 로 일반수혈검사의 참여기관 수가 전년도 에 비하여 많이 증가하였다. 이는 전년도 분석과 마찬가지로 2017년 7월부터 건강보험 등에 '검체검사 질가산'제도가 신설 됨에 따른 영향으로 여겨진다[2].

2017년부터는 실제 검사실 환경을 반영하기 위하여 정도관 리용 검체를 $20 \%$ 의 재조합 전혈이 되도록 농축적혈구와 세포 보존액으로 희석하여 제조하였다. 전혈 $20 \%$ 는 $15 \%$ 로 알려진 호주의 정도관리프로그램인 Royal College of Pathologists of Australasia의 검체보다 적혈구 농도가 높아 실제 환자 검체 와 더 유사하게 제조하고자 하였다. 그러나 일부 자동화 장비 에서는 여전히 세포보존액 때문에 혈청형 검사가 불가능한 경 우도 있어 이들 기관에 한해서는 동형의 신선동결혈장과 항혈 청을 첨가하여 유사한 $\mathrm{ABO}$ 항체 역가를 가지도록 제조하였 다. 따라서 참여기관의 자동화 장비의 종류에 따라 목표 결과 값은 일정하되 외부신빙도 검체 조성은 달리 만들어야 될 필요 도 있겠다.

2017년도에는 일반수혈검사의 혈구응집 강도를 모두 시범 항목으로 간주하여 평가에서 제외하였으나, 2018년 평가에서 는 혈구응집 강도를 혈액형 결과입력프로그램의 입력 필수사 항으로 변경하였고 이를 안내문에 공지하였다. 즉 혈액형검 사 시는 응집 정도를 선택하여 입력한 후 판정에 최종 혈액형 을 입력하도록 하였고, $\mathrm{ABO}$ 혈액형검사 시 혈구형만 실시하 였을 경우 혈청형 검사의 A cell과 B cell의 2개 항목을 부적합 으로 처리한다고 공지하였다. 이러한 영향 덕분으로 2018년에 는 참여기관 모두가 혈액형검사에서 혈구 응집 정도를 입력하 였고 $\mathrm{ABO}$ 혈액형검사의 경우 혈구형과 혈청형을 함께 시행 하는 성과를 가져오게 되었다. 2017년도 1차와 2차의 경우 혈 청형 검사를 실시하지 않은 기관의 비율이 $4.7 \%$ 와 $5.5 \%$ 를 차 지하였다는 사실을 고려할 때 매우 고무적인 현상이라고 할 수 있다[2]. 따라서 결과입력프로그램의 변경과 꾸준한 안내문의 공지는 참여기관의 교육효과에도 매우 효율적임을 알 수 있었 다. 그러나 혈액형검사에 참여하는 총 기관 수는 증가한 대신 전년도에 비하여 슬라이드법을 시행하는 기관은 증가하였고, 권장되는 시험관법은 감소하였다.

부적합 교차시험 검체의 정답률은 전년도에 비하여 상승하 였으나, 전년도와 마찬가지로 시험관 식염수법에서 양성을 보
고하거나 시험관 항글로불린 단계에서 음성을 보이는 기관들 이 여전히 존재하여 이들 기관에 대한 올바른 교차시험 검사법 교육이 필요한 것으로 여겨졌다.

$\mathrm{ABO}$ 아형 검사의 정답률은 전년도 $96.0 \%$ 와 $80.7 \%$ 에 비하 여 상승한 $94.2 \%$ 와 $94.4 \%$ 를 보여 향상된 결과를 보여주었는 데, 이는 B 아형에 대한 항-B 시약의 혈청형 검사에서 $3+$ 이 상의 응집을 보이는 기관이 1 차에는 $19.2 \%, 2$ 차에는 0 개 기관 으로 매우 감소하였기 때문으로 분석되었다. 그러나 2 차 검체 에서 $\mathrm{B}$ 항원을 검출하지 못한 기관도 2 기관이나 되었기에 전년 도에 비하여 대부분의 참여기관들이 $\mathrm{B}$ 아형을 판정하는 능력 이 향상되었지만 2 차 검체가 다른 시기의 검체에 비하여 $\mathrm{B}$ 항 원이 더 약하기 때문에 정상 $\mathrm{B}$ 형으로 판정하는 경우도 감소하 였기 때문인 것으로 생각되었다. 약하게 표현되는 $\mathrm{ABO}$ 아형 들은 잘못 검사 시 $\mathrm{O}$ 형으로 판정될 수 있다 $[3,4]$. 이를 검출하 지 못하여 정확하게 혈액형을 판정하지 못할 경우 수혈자는 동 일한 혈액형의 혈액을 수혈받는데 특별한 문제가 없을 수 있으 나, 헌혈자는 환자에게 항체를 유발하거나 용혈수혈 이상반응 을 초래할 가능성이 있다. 따라서 혈액원이나 혈액원을 운영하 는 의료기관에서의 헌혈자의 혈액형검사는 매우 중요하며, 혈 액원을 운영하지 않는 의료기관도 환자에게 정확한 혈액형을 정보를 전달해 준다는 점에서 약한 $\mathrm{ABO}$ 아형 검출에 대한 중 요성이 더 강조될 필요가 있다.

$\mathrm{D}$ 변이형 중 부분 $\mathrm{D}$ 는 시약에 따라 응집반응의 유무가 달라 질 수 있으므로 $\mathrm{D}$ 변이형 검체의 $\mathrm{RhD}$ 혈액형검사는 평가에 포함하지 않았다. 2017년 D 변이형 검체와 2018년 1차 검체 는 $\mathrm{RhD}$ 혈액형검사에서 정상 $\mathrm{D}$ 양성에 비해서는 약하지만 응 집을 보인 $\mathrm{D}$ 변이형 검체였다. 이러한 검체들은 $\mathrm{RhD}$ 혈액형 검사에서 $\mathrm{D}$ 항원이 이미 검출되었으므로 weak $\mathrm{D}$ 검사를 시행 하지 않고 'not done'으로 보고한 기관들도 적합으로 평가하였 다. 이러한 검체를 D 변이형으로 보고한 기관의 비율은 2017 년도 $51.7 \%, 78.7 \%$ 그리고 2018년 1차 검체는 정답률로 평가 한 $80.9 \%$ 로 2017 년 1 차 검체에 비하여 참여기관들의 D 변이 형 판정률이 증가하였음을 알 수 있었다. 반면 2018년 2차 검 체는 weak $\mathrm{D}$ 검사에서도 음성을 보이는 기관들이 $63.6 \%$ 를 보 일 만큼 약한 $\mathrm{D}$ 항원을 가진 $\mathrm{D}$ 변이형으로 참여기관의 합의를 도출하지 못하여 평가에서 제외하였는데, 추가검사로 weak partial 15 이 의심되었던 검체였다. 국제수혈학회의 $\mathrm{RH}$ 대립 유전자 명명 가이드라인에 의하면 partial D형은 항원 결정기 의 일부가 소실되어 항-D 항체를 유발한 위험이 있는 혈액형 인 반면 weak $\mathrm{D}$ 형은 일부 예외를 제외하고는 항원 결정기의 소실이 없으므로 항-D 항체 유발 위험이 없는 혈액형으로 명 명하였는데, 이 예외규정에 항-D 항체를 유발한 위험이 있는 
weak D형을 weak partial D형으로 명명하였다[5]. Weak D 형 중 type 11,15 와 21 들은 여기에 속하며 이들은 다양한 항 원 결정기의 변형으로 항-D 항체를 생산할 수 있는 것으로 알 려져 있다[6,7]. 이러한 weak partial D형은 다른 D 변이형 검체에 비하여 $\mathrm{D}$ 항원이 저하되어 있을 뿐만이 아니라 일부 항 원 결정기가 소실되었으므로 weak D검사에서도 음성을 보일 수 있겠으나 헌혈자를 비롯하여 신생아와 산모에서는 반드시 검출하여야 한다는 점에서 D 음성으로 보고한 기관들의 weak $\mathrm{D}$ 검사의 점검이 필요하겠다.

$\mathrm{ABO}$ 항체 역가검사법 중 시험관법 실온배양이 예년처럼 정답률이 가장 높았는데, 예년에는 원주응집법이 시험관법에 비하여 정답률이 높았던 반면 금년에는 시험관법이 더 높은 양 상을 나타내었다.

2018년에는 참여기관 수가 전년도에 비하여 평균 $10.5 \%$ 더 증가하였으며, 예년과 마찬가지로 4 개의 수혈의학프로그램의 10 가지 종목을 시행하였고 이에 대한 결과를 분석하여 발송하 였기에 참여기관들의 검사실 향상에 도움을 주었을 것으로 평 가할 수 있었다.

\section{REFERENCES}

1. Lim YA, Cho HS. Annual report on the external quality assessment scheme for immunohematology testing in Korea (2016). J Lab Med Qual Assur 2017;39:107-16.
2. Lim YA, Cho HS. Annual report on the external quality assessment scheme for transfusion medicine in Korea (2017). J Lab Med Qual Assur 2018;40:9-20.

3. Whang DH, Shin BM, Lee HS, Hur M, Han BY, Han KS. Unusual phenotype expression in a Cis- $\mathrm{AB}$ trait: Cis- $\mathrm{AB}$ child from a group A father and a group O mother. Korean J Blood Transfus 2000;11:169-75.

4. Cho D, Jeon MJ, Song JW, Lee JS, Choi HW, Kwon SY, et al. Serologic variability of the $\mathrm{A}(\mathrm{var})(784 \mathrm{G}>\mathrm{A})$ and its property of different expression depending on co-inherited ABO allele. Korean J Blood Transfus 2006;17:61-70.

5. International Society of Blood Transfusion. Red cell immunogenetics and blood group terminology. http://www. isbtweb.org/working-parties/red-cell-immunogeneticsand-blood-group-terminology/. (Accessed May 24, 2019).

6. Takeuchi-Baba C, Ito S, Kinjo R, Miyagi H, Yasuda H, Ogasawara K, et al. Production of RBC autoantibody mimicking anti-D specificity following transfusion in a patient with weak D Type 15. Transfusion 2019;59:11905.

7. Ishii T, Ogura W, Kojima N, Sekiguchi K, Takagi Y, Onishi H. A case of weak partial D type 15 diagnosed by genetic analysis. Jpn J Med Technol 2018;67:785-90. 